\title{
古紙利用の現状と今後の課題
}

日本製紙株式会社 研究開発本部開発企画部 竹下登

\section{Present Status of Paper Recycling and Future Subjects}

\section{Noboru Takeshita}

Nippon Paper Industries Co., Itd. R\&D Planning Dept.

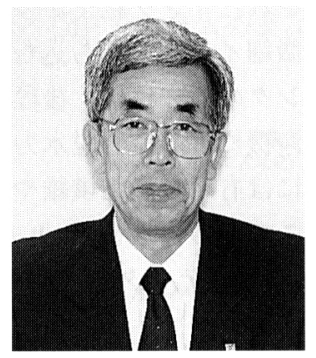

Recently the utilization rate of used paper had been increasing dramatically, may achieve $58 \%$ in 2001. It was mainly due to decreasing in the market price of collected used paper because of increase in the collecting volume, the increasing cost difference with wood chip, the progressing of de-inking technology, and the stronger demand of recycle product at the market. De-inked pulp is likely to be used for wood free products today. At the poor market situation wood-free coated paper is decreasing in sales, however coated paper which contains recycled pulp has been sold $120 \%$ over the last year. This trend will be continued.

Comparing the energy consumption in the production process for each pulp, used energy of DIP was the lowest, but it came from only fossil fuels. On the other hand used energy of chemical pulp was bigger than that of DIP, but less fossil fuels consumed because some part of energy can be provided by itself.

In order to construct recycling-oriented industry, it is necessary to set up and proceed the two recycling systems, namely a forest recycle to immobilize carbon dioxide and regenerate forest resources, and used paper recycle to save resources and energy. Japan Paper Association decided 60\% as a target of utilization rate of waste paper in 2005. To achieve the figure, it is essential to cooperate between governments, related industries, and consumer. They should make efforts to use more recycle products, to achieve a preferable product quality, to collaborate a complete fractional recovery and an effective recycle system of office waste.

分類： $A_{5}$ 古紙原料, $G_{1}$ 古紙一般

\section{1.はじめに}

製紙産業では古くから，古紙利用を進めてきている。 まず板紙への利用からスタートし, 1970 年代には新聞 用紙，中下級紙への利用が進んできた。その後 1990 年代前半にごみ問題に端を発して, 森林資源問題がか らみ，再生紙ブームが起こってきた。
その結果として再生紙イコール環境に優しいという 代名詞のように使われている例も多い。更に循環型社 会構築に対する社会的要請などに伴い, 一段と古紙利 用が進んできている。

しかし，古紙利用は資源保護や省エネルギー，循環 型社会及び産業構築といったような全体的, 多面的視 野で考えるべきである。 
ここでは製紙産業の古紙利用, 再生紙製造の全体像 を展望し，今後の課題について整理してみたい。

\section{2. 製紙産業の概要}

古紙利用の現状と今後の課題を理解するためには製 紙産業の全体像を知る必要があり, 本題に入る前に,

製紙産業の概況について述べる。

紙の生産量はGDP 成長率と連動して,これまでは 右肩上がりで成長し, 2000 年現在で, 紙の年間生産量 は 1,900 万トンとなっている。板紙は 1990 年以降微 増で, 現在 1,280 万トン, あわせて 3,190 万トン生産 している。これまでは順調に成長してきたが, 2001 年 は日本全体の不況とも関連して, マイナス成長（対前 年比約マイナス $1.9 \%$ の見込み）となり, 2002 年は紙

・板紙計で 3,120 万トン, 対前年比マイナス $0.9 \%$ と 予測される（日本製紙連合会）など，今後の成長も予 断を許さない状況にある。

2000 年の紙の品種別売上，生産量を表 1 に示す。 紙では微塗工・塗工印刷用紙が生産量 673 万トン, 売 上 6,910 億円と最も多く, ついで新聞巻取紙, 非塗工 印刷用紙，情報用紙，衛生用紙の順になっている。

板紙ではライナーが最も多く, 白板紙, 中芯原紙の 順になり, 生産量は合計 1,280 万トン, 売上 6,730 億
円となっている。

紙の大手ユーザーである出版向け及び印刷向けの出 荷量をみてみると, 出版向け 210 万トン, 印刷向け 474 万トンとなり, 印刷用紙の $71 \%$ が出版・印刷向 けとなっている。ここ数年出版向けは漸減, 印刷向け は漸増傾向にある。

平均販売価格は紙で 118 円 $/ \mathrm{kg}$, 板紙で 53 円 $/ \mathrm{kg}$, 製紙業全体で 92 円 $/ \mathrm{kg}$ であり, 製紙産業は安価な製 品を大量に製造販売している産業である。

これらの紙の多くは大なり，小なり古紙を使用して いる。従って古紙, 再生紙を検討する場合, 例えばコ ピー用紙のように一品種の再生紙のみを考えるのでは なくて, 紙全体を展望していく必要がある。

\section{3. 古紙リサイクルの現状}

図 1 に古紙回収率と利用率の推移を示す。なお回収 率と利用率の定義は次のようになっている。

\section{古紙利用率}

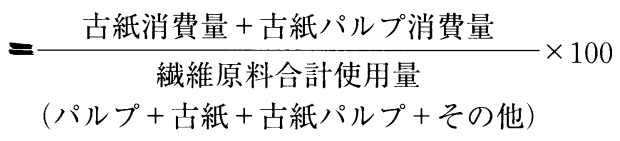

表 1 紙の品種別売上, 生産量

\begin{tabular}{|c|c|c|c|}
\hline \multicolumn{4}{|c|}{2000 年 } \\
\hline & 品 & 販売高 (10億円) & 生産量(千トン) \\
\hline \multirow{8}{*}{ 紙 } & 新聞巻取紙 & 400 & 3,419 \\
\hline & 非塗工印刷用紙 & 292 & 2,889 \\
\hline & 微塗工·塗工印刷用紙 & 691 & 6,730 \\
\hline & 情報用紙 & 169 & 1,737 \\
\hline & 包装用紙 & 111 & 1,049 \\
\hline & 衛生用紙 & 300 & 1,735 \\
\hline & その他の紙 & 276 & 1,477 \\
\hline & 紙 & 2,239 & 19,037 \\
\hline \multirow{5}{*}{$\begin{array}{l}\text { 板 } \\
\text { 紙 }\end{array}$} & ライナー & 272 & 5,790 \\
\hline & 中しん原紙 & 139 & 3,886 \\
\hline & 白板紙 & 174 & 1,851 \\
\hline & その他板紙 & 88 & 1,265 \\
\hline & 板紙 & 673 & 12,791 \\
\hline & · 板 紙 & 2,913 & 31,828 \\
\hline
\end{tabular}


古紙回収率

$$
\begin{aligned}
& \text { 古紙国内回収量 } \\
& =\frac{(\text { メーカー入荷 }+ \text { 輸出 }- \text { 輸入 })}{\text { 紙 } \cdot \text { 板紙国内消費量 }} \times 100
\end{aligned}
$$

各方面の努力もあり, 1988 年以来共に上昇を続け, 古紙利用率は 2000 年に $57 \%$ に達し, 2001 年には $58 \%$ に到達すると予想されている。

近年古紙利用率が上がってきた要因としては古紙の 回収量増加による古紙市況価格の低下と木材チップと の価格差の拡大，DIP 技術・利用技術の進歩，古紙利 用製品需要拡大などがあげられる。

後述するが，製紙連合会では 2005 年に古紙利用率 $60 \%$ を掲げて, 目標達成のため諸施策を実施してい くことになっている。

図 2 は古紙全体の発生・流通経路を示したものであ る。発生源は家庭, 市中, 小規模及び大規模発生坪の 4 箇所で，ここで集荷された古紙は古紙業者を経て， 製紙メーカーに納入される。その量は 2000 年で年間 1, 800 万トンに及んでいる。この古紙と国産及び輸入 のバージンパルプ 1,350 万トンから紙・板紙 3,180 万 トン製造している。その $95 \%$ が国内で消費され，大
部分が古紙となってリサイクルされる。

回収不能品も含めて，未回収分は 1,330 万 (42\%) となっており, 発生量の $58 \%$ が回収ルートに回って いる。

このルートに乗っている古紙は経済原則で流通する が，このルートに乗っていない古紙を回収しょうとす

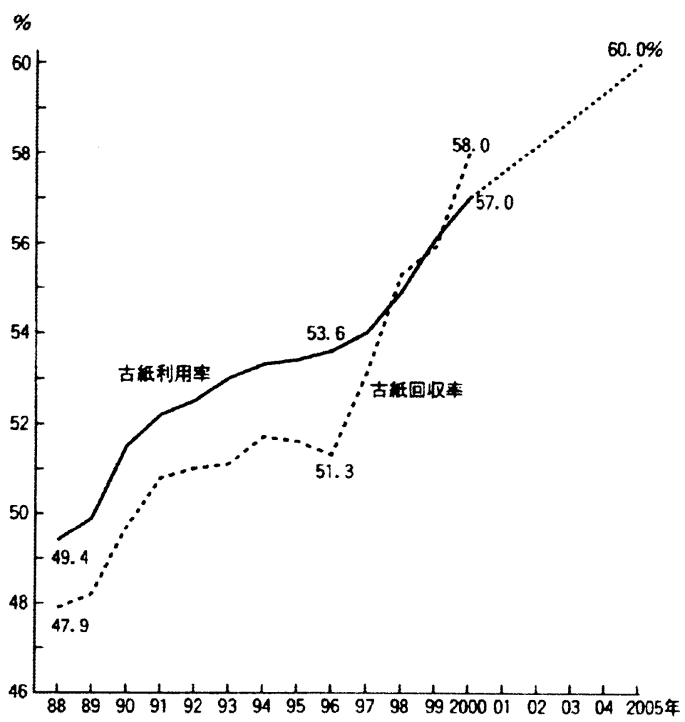

図 1 古紙の利用率と回収率の推移"

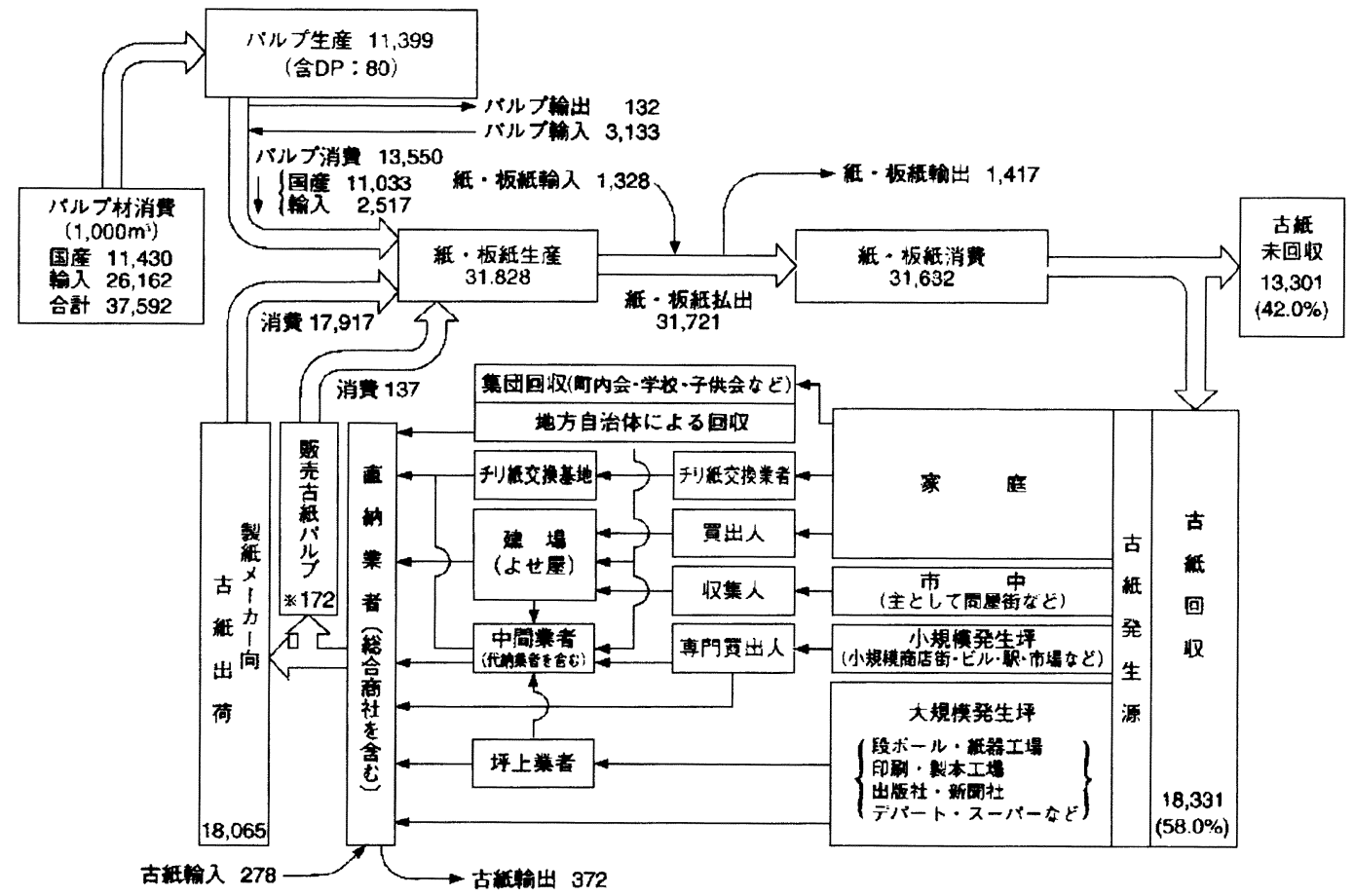

図 2 古紙全体の流通とリサイクル2 


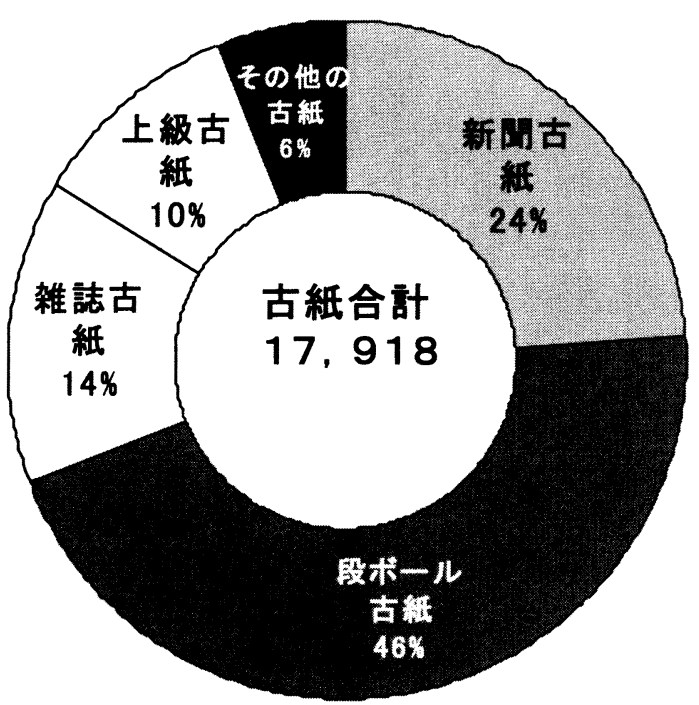

図 3 古紙品種別構成比 ${ }^{11}$ (単位：千トン)

るとき，多大な努力やコストがかかることになり，い かに效率良く集荷するシステムを作っていくかが，今 後の課題の一つである。

日本は諸外国と比較すると狭い国土で多量の紙を消 費しているため, 古紙マーケットとしては非常に条件 の優れた国である。そのため経済原則が成立しやすく， 世界有数の古紙利用国になっている。

しかし近年ゴミ問題などから，経済べースに乗りに くい古紙を回収せざるを得なくなってきたこと, 及び 各企業が自社のイメージアップに利用するなどの動き もあって，やや複雑になってきている。

図 3 に古紙品種別消費量の構成比を示す。最も集め やすく, 利用先もきまっているダンボール古紙が $46 \%, 820$ 万トンと最も多く, ついで新聞古紙は $24 \% ， 430$ 万トン, 雑誌古紙 $14 \% ， 250$ 万トンとなっ ている。上級古紙はまだまだ集荷量が少なく, 全体か らみれば $10 \%$ のレベルである。

これまでは集めやすい, 古紙パルプ化がしやすい, 価格が適正であるといった条件にかなう古紙から順番 に集荷されてきた。今後回収を増やしていくにはこれ まで種々の要因により集められていなかった古紙を如 何に集荷・利用していくかが今後の課題である。

少し視点を変えて製紙原料のソース別構成を見てみ ると, 古紙は製紙原料全体の 56\%（1999 年）を占め る主要原料である（図 4)。

よくこの紙は何\%再生紙という表現を目にするが, 日本全体でいえば $56 \%$ 再生紙を使っていることにな る。
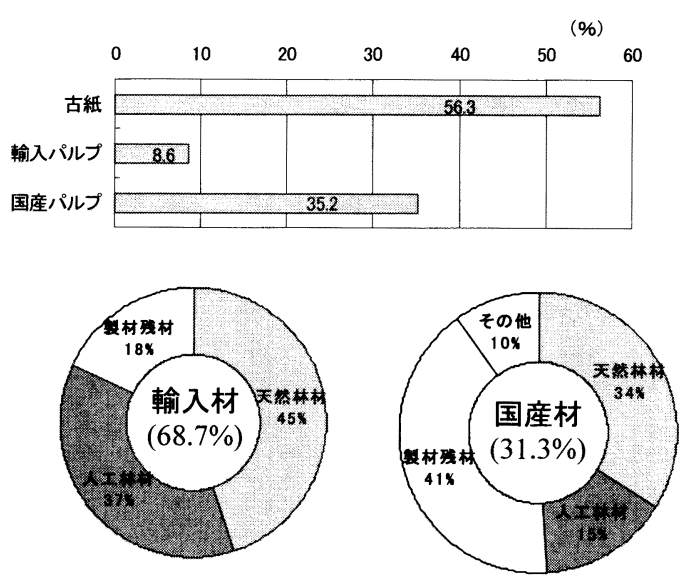

図 4 製紙原料のソース別構成 ${ }^{3 \prime}$

国産パルプは $35 \%$ ，輸入パルプは $9 \%$ の割合であ る。ちなみに国産パルプを製造する上での使用木材の 内訳を見ると, 輸入材は国産材の 2.2 倍を占め, 中味 は人工林材と製材廃材合わせて $55 \%$ ，低質の天然林 材 $45 \%$ からなっている。国産材も人工林材, 製材廃 材合わせて $56 \%$ となっている。

\section{4. 製紙産業の資源問題への取り組み}

ここで本題とは若干ずれるが，古紙とは関連の深い 製紙産業の資源問題への取り組み，特に植林について 触れてみる。

製紙産業は表 2 に示すように, 資源の安定確保を目 指して, 積極的に植林, 特に海外植林に取り組んでい る。地域はオーストラリア, チリ, 南アフリカ, 中国 などである。樹種は主に早成樹のユーカリで, この木 は成長が早く, 約 8 年でパルプ用材として伐採可能で あり，またパルプ化適性も優れている。

すなわち 8 年分の土地があれば, 1 年ずつ切って, その後植林していけばリサイクル可能である。実際に このようなツリーファームが南米などでスタートして いる。

近年日本側企業としては商社, 出版社, 電力会社, 自動車メーカーなどが炭酸ガス排出権取引や企業のイ メージアップを目的として，植林事業に参画してきて いる。

但しこの海外植林は旱魅や病虫害による被害, 政情 不安，資金回収に時間がかかるなど非常にリスクも多 W。

図 5 は日本製紙の海外植林プロジェクトを示したも のである。オーストラリア，チリ，南アフリカを中心 に現在 4 万 haの植林を行っている。2008 年には 10 


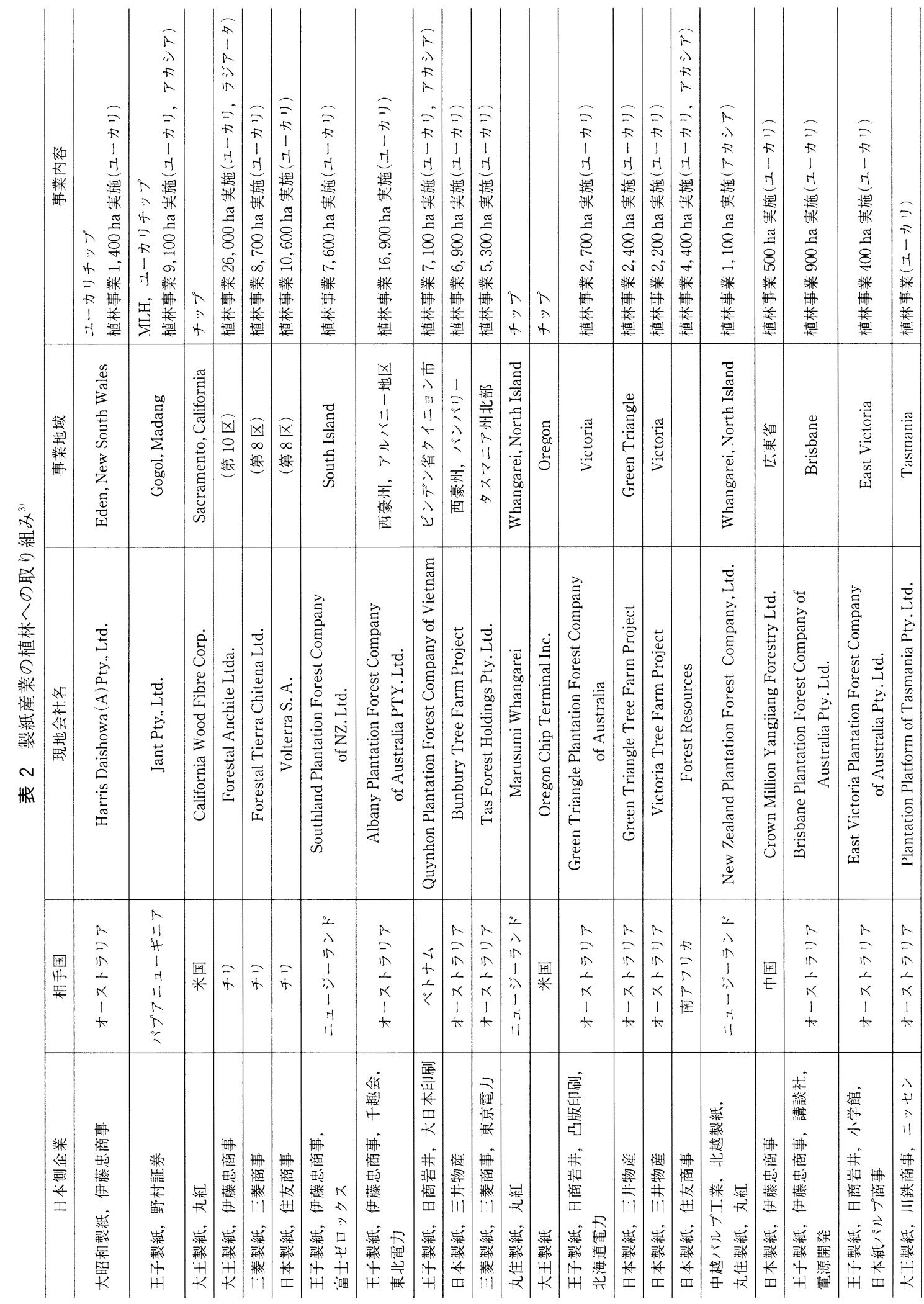




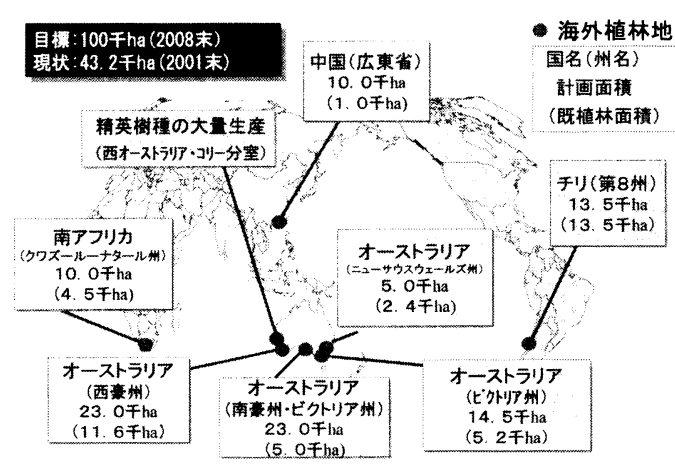

図 5 日本製紙の海外植林プロジェクト ${ }^{4}$

万 haの植林を行い, 年間 100 万トン以上の木材チッ プを供給することを目標としている。この量は同社の 輸入木材チップの $70 \%$ に相当する。

図 6 は製紙産業が目指している循環型産業構築の仕 組みである。その主要部分は必要なバージン原料を植 林で行う森のリサイクルと古紙を利用する紙のリサイ クルである。

森のリサイクルでは炭酸ガス固定化・資源再生を目 的とした植林及びその管理, 紙のリサイクルでは資源 節減・省エネルギーを目的とした古紙利用率向上が重 要であり,この二つのリサイクルをバランス良く, 進 めていかねばならない。

またこのリサイクルを達成するための技術開発も重 要となってくる。この分野の日本製紙の研究開発の一 端を紹介すると, 森のリサイクルではバイオテクノロ ジーを利用した早成樹開発を行っている。すなわち遺 伝子導入による成長の早い樹木, 対病, 耐寒性の優れ た樹木の開発, 成長の早い樹木のクローンによる増殖 などの研究を行っている。

一方紙のリサイクル関連ではオフィス古紙など未利 用古紙の利用技術開発などを積極的に行っている。

\section{5. 古紙パルプ, 再生紙の現状}

これまでは古紙を中心に述べてきたが，これからは 個別古紙原料とそれを使用した再生紙について解説す る。

図７は集荷された古紙がどのような紙・板紙に使用 されるかを示したものである。黒の実線は当該古紙の 全消費量が $30 \%$ 以上, 破線は当該古紙の全消費量が $30 \%$ 未満に相当する。

ダンボール古紙はメインはダンボール原紙用である が，その他種々の用途に用いられている。新聞古紙も メインは新聞巻取紙であるが, 近年脱墨パルプ製造技 術の進歩に伴い，印刷用紙に用いられるようになって

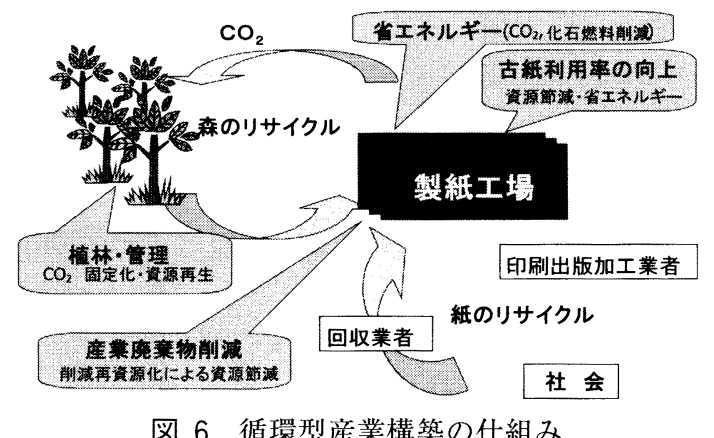

図 6 循環型産業構築の仕組み

きた。このようにそれぞれ適した使い方がある。近年 特定古紙をもとの用紙に用いるというクローズドルー プのような使い方が種々提案されている。

結果的に再生紙生産量が増えて, 古紙利用率も向上 するという利点はあるが，それぞれの古紙は最も使い やすい所で使用する方がベストであり，全体として利 用率を上げていくという方向がより望ましい。

古紙の品種別回収率を見ると, 古紙の最大品種であ るダンボール系は回収率 $83 \%$ と八イレベルにある。 新聞回収率は $118 \%$ と $100 \%$ を超えているが，これは 折り込みチラシを加えたものであり, 最近ではチラシ 量が 30\%〜 40\%あるため, 新聞の実質回収率は約 $70 \%$ であり，更に回収可能である。

紙の主要製品である印刷出版用紙はまだ回収率が $33 \%$ と低い。この理由は集めにくい，使いにくい， 価格が安いなどの理由による。全体の回収率を上げる ためにはこれらの古紙を安価に効率良く回収する方法 の確立が今後の課題の一つである。

表 3 に古紙の品種別消費原単位を示す。板紙系はほ とんど古紙 $100 \%$ である。板紙全体を見ても原単位は 0.96 となっている。紙関係では新聞用紙と衛生用紙 の古紙原単位が高く, 新聞巻取紙は 0.60 と 10 年前と 比較して 0.13 アップしている。

これらの紙は再生紙化が進んでいるのに対して,メ インの印刷用紙は 10 年前の 0.15 と比較して, 0.21 と上昇しているものの, まだまだ低く, 再生紙化が遅 れている。全体の原単位を上げるにはこの数值を更に アップする必要があるが, 一方で厳しい品質基準との 兼ね合いでもある。

古紙価格も再生紙を製造する上での重要なファクタ 一である。表 4 は主要古紙 3 品種の製紙メーカー購入 価格である。この值は古紙の需給バランスと共に上下 する。

古紙問屋仕入価格は選別・包装・運搬などの費用が 
【古 紙】
【紙・板紙】

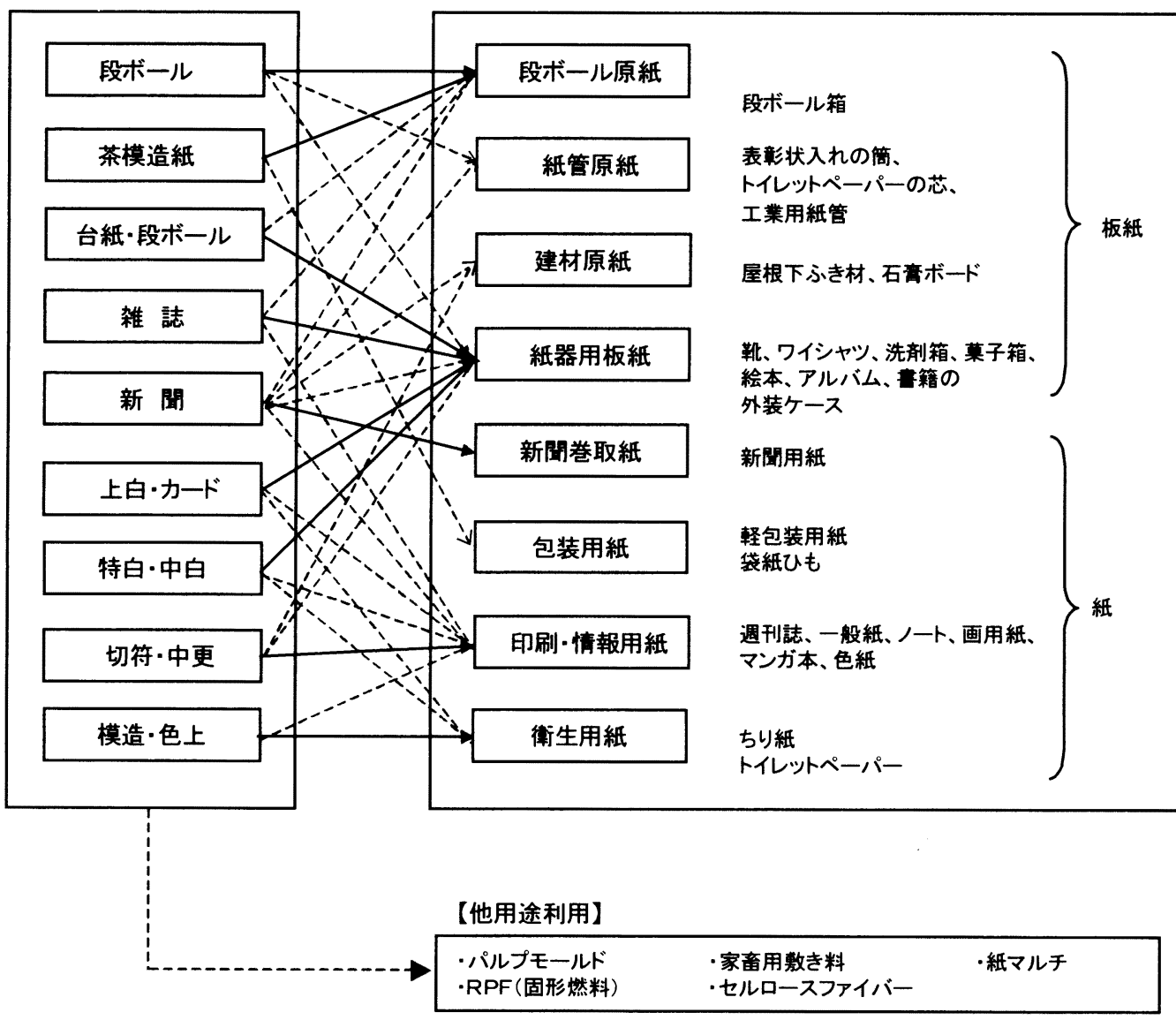

図 7 古紙が配合される紙・板紙 ${ }^{5}$

かかるため, 製紙メーカー購入価格の 6 円前後安い值 段となる。したがって雑誌古紙が值崩れすれば，古紙 問屋の段階で逆有償になる。

このところ不況のせいか, 古紙が余ってきており， 直近のデータでは新聞古紙が 9 円，雑誌古紙が 5.5 円 に値下がりし，雑誌古紙は問屋段階で逆有償のレベル になりつつある。

逆有償になれば，廃棄物処理法の適用も受ける可能 性があり，新たな問題となってくる。

またこのレベルのコストであれば，木材チップより 製造したバージンパルプより，コスト的にメリットが あり，古紙利用はどんどん進んでいく。但し上白古紙 のように高い古紙を使用して再生紙を作れば，コスト 的にはバージンパルプより高くなることもあり，メリ ットはほとんど無くなってくる。
30 年間というスパンで古紙価格の変動をみると段 ボール古紙は $\mathrm{kg}$ あり 8 円〜40 円，新聞古紙は 10 円〜40 円，雑誌古紙は 5 円〜30 円と大きく変動して いる。1990 年代後半より, 自治体による古紙回収シ ステムの拡充等で, 需給バランスが崩れ，これらの古 紙主要 3 品は価格が下落し, 現在は最も安值のレベル にある。したがって木材チップとの価格差も大きくな り，古紙利用率のアップに大きく寄与している。

新聞用紙や中質系の用紙については以前から多量の 古紙パルプが使われている。・方最近では上質系にも 再生紙の波がきつつある。最近の市場では上質紙，コ 一ト紙とも売れ行きが悪く，図８に示すように対前年 比 $100 \%$ 以下のものが多い。再生紙は販売量から見る と全体の約 $5 \%$ と推定され，まだ量は少ないものの, 伸び率は対前年比 $120 \%$ と非常に高くなっている。こ 
表 3 古紙の品種別消費原単位

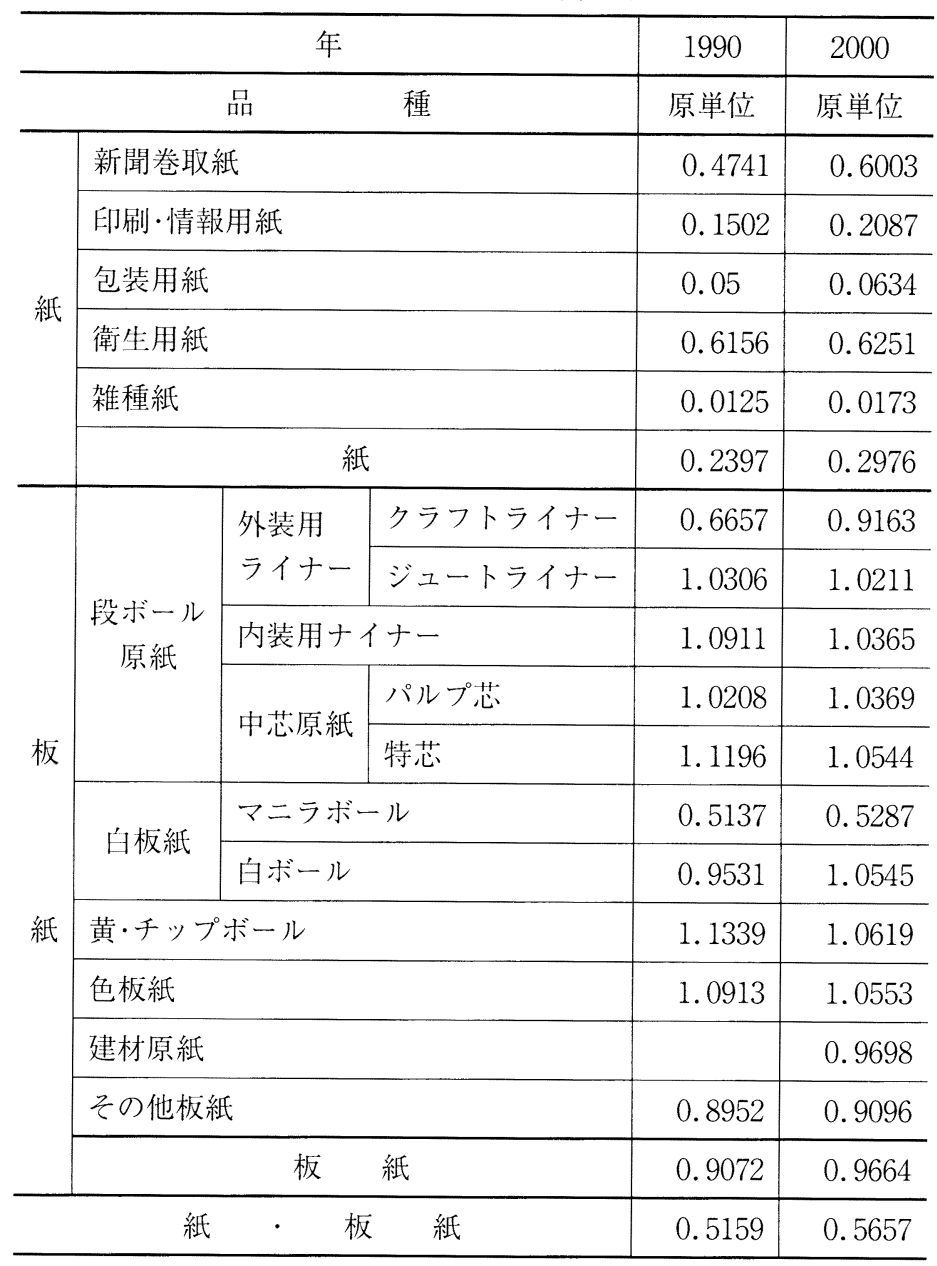

れはグリーン購入法などの影響と思われ，今後も更に 加速するものと思われる。

PPC 用紙では輸入紙の拡大（主にインドネシア）と 再生紙化の二つの動きがある。

PPC 市場は 2000 年で年 100 万トンで，輸入紙が 20 万トン，国産が 80 万トンであるが（図 9)，国産分の 内約 35 万トン，比率に直すと約 $45 \%$ が再生紙になっ ており,グリーン購入法からみやハードメーカーの方 針を加味すると，その動きは更に加速するものと予想 される。

再生紙では古紙配合率 70\% 物と $100 \%$ 物，白色度 は 70\% 物と上質紙並みの $80 \%$ 以上品がある。市場二 ーズは $100 \%$ 再生紙で高白色度品が要望されている。

しかし，後述のように環境面を考慮すれば，低白色 度品が望ましく, また積極的にPRして行く必要があ る。

\section{6. 再生紙の環境評価}

再生紙は環境に優しいという代名詞の如く使用され ているが，環境評価という視点で考察してみたい。図 10 は化学パルプに古紙パルプを配合して, 再生紙を 製造した場合の古紙パルプ配合率と炭酸ガス排出量を 示したものである。古紙パルプの配合率を増やせば, トータルのエネルギーは減少し, それに応じて全体の 炭酸ガス量は減少する。

しかし中味を見てみると, 再生可能なバイオマス由 来の炭酸ガス発生量は大きく減少するが, 化石燃料由 来の炭酸ガスはむしろ増加する。化石燃料のみに着目 すれば，再生紙を作るほど化石燃料を余計に消費する ことになる。これは化学パルプが全エネルギーすなわ ち炭酸ガス発生量は多いが, 大部分は再生可能な木材 (バイオマス) 由来のエネルギーでまかなえるのに対 
表 4 古紙価格の推移

\begin{tabular}{|c|c|c|c|}
\hline & & \multicolumn{2}{|c|}{ (単位:円/kg) } \\
\hline & 新聞古紙 & 段古紙 & 雑誌古紙 \\
\hline 98. 1 & 11.5 & 10.0 & 5.0 \\
\hline 3 & 10.5 & 9.0 & 5.0 \\
\hline 6 & 10.5 & 9.0 & 5.0 \\
\hline 9 & 10.5 & 9.0 & 5.0 \\
\hline 12 & 10.5 & 8.5 & 4.7 \\
\hline 99. 3 & 10.5 & 7.5 & 4.7 \\
\hline 6 & 10.5 & 7.5 & 4.7 \\
\hline 9 & 11.0 & 7.5 & 5.7 \\
\hline 12 & 11.0 & 7.5 & 7.0 \\
\hline 0.03 & 11.0 & 8.0 & 7.0 \\
\hline 6 & 11.0 & 9.0 & 7.0 \\
\hline 9 & 11.0 & 9.5 & 7.0 \\
\hline 12 & 11.0 & 9.0 & 7.0 \\
\hline 01. 1 & 11.0 & 9.0 & 7.0 \\
\hline 2 & 10.5 & 8.0 & 7.0 \\
\hline 3 & 10.0 & 8.0 & 7.0 \\
\hline 4 & 10.0 & 8.0 & 6.5 \\
\hline 5 & 10.0 & 8.0 & 6.5 \\
\hline 6 & 10.0 & 8.0 & 6.0 \\
\hline 7 & 10.0 & 7.5 & 6.0 \\
\hline 8 & 9.5 & 7.0 & 5.7 \\
\hline 9 & 9.0 & 7.0 & 5.5 \\
\hline 10 & 9.0 & 6.0 & 5.5 \\
\hline 11 & 9.0 & 6.0 & 5.5 \\
\hline 12 & 9.0 & 6.0 & 5.5 \\
\hline
\end{tabular}

して, 古紙パルプはトータルのエネルギーは少ないも のの全て化石燃料由来のエネルギーを使用するためで ある。

図 11(a)は KP, TMP, GP, DIP 単独でモデル的に新 聞用紙を作製し，そのLCA 評価を行ったものである。 KP は大部分木材チップのエネルギーを利用して作る ので, 大半はバイオマスエネルギーである。TMPや GP はリファイナーやグラインダーを動かすエネルギ

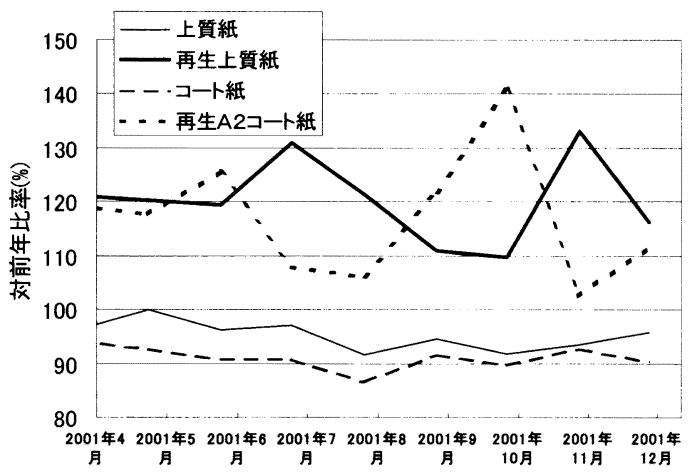

図 82001 年再生紙製品の伸び率

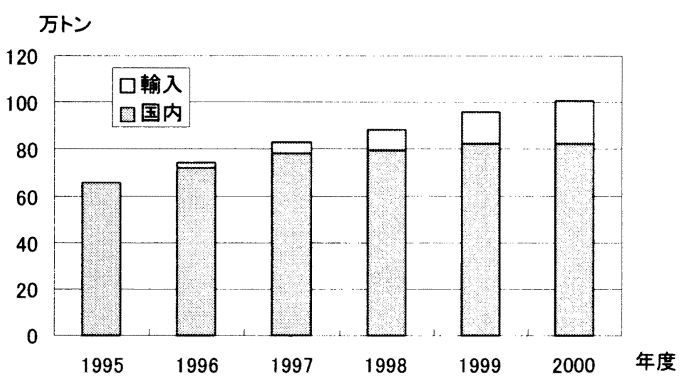

図 9 PPC 国内市場規模推移

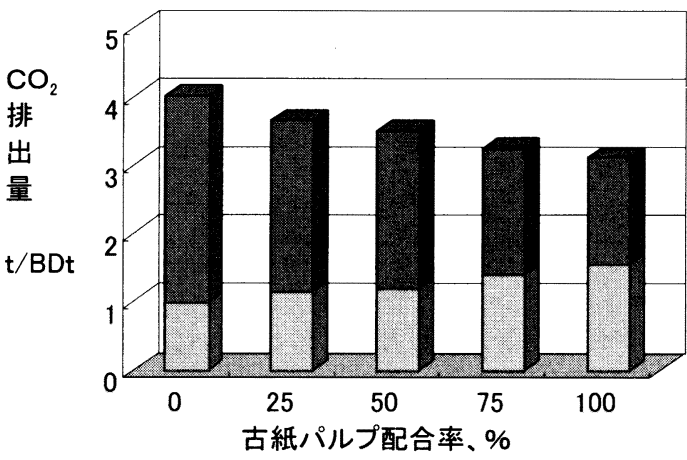

口化石燃料 $\mathrm{CO}_{2}$ ロ ロバイオマス $\mathrm{CO}_{2}$

図 10 再生紙の古紙配合率と炭酸ガス発生率”

一がメインで，そのエネルギーが多量なため，ほぼ $100 \%$ 化石然料由来となる。

DIP は古紙を，機械エネルギーを使用して異物やイ ンキを除去して作るため, 必要エネルギーは最も少な くなるが，ほとんど化石燃料由来である。

このエネルギーのデータを基に, 計算した炭酸ガス 発生量を図11(b)に示す。この数值は製品を廃棄した 場合の炭酸ガス発生量も含んでいる。LCA とは摇り 


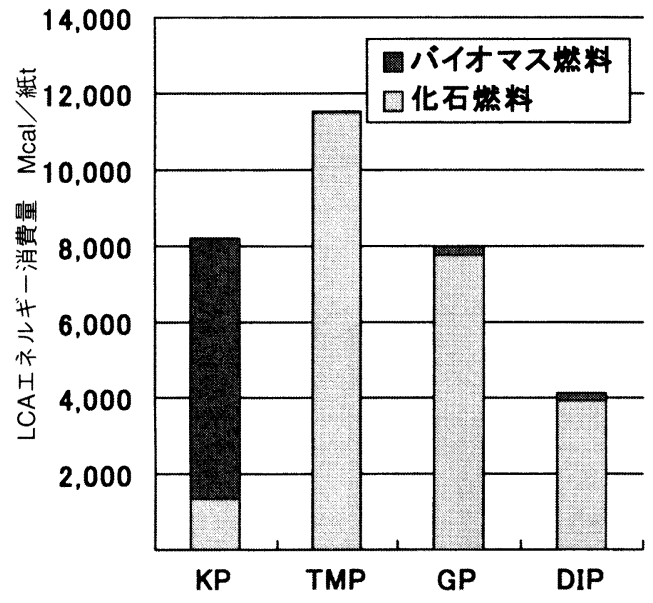

（a）LCA エネルギー消費量 $\mathrm{Mcal} /$ 紙 $\mathrm{t}$

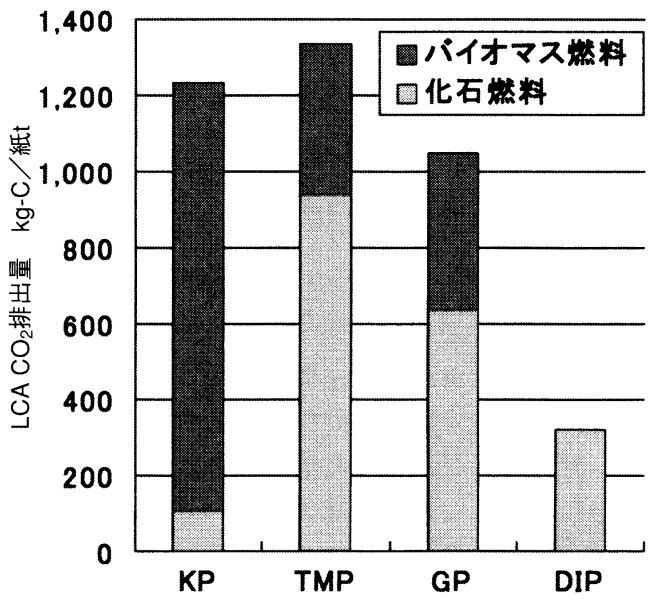

(b) $\mathrm{LCA} \mathrm{CO}_{2}$ 排出量 $\mathrm{kg}-\mathrm{C} /$ 紙 $\mathrm{t}$

図 11 各種パルプ 100\% での新聞用紙の LCA の評価 ${ }^{8}$

籠から墓場までの全体を見るものであるが，種々の前 提条件を設定して，計算したものである。

この図からわかるように, トータルの炭酸ガスは発 生量は TMP, KP, GP, DIP の順に少なくなる。但し化 石燃料由来の炭酸ガス発生量は TMP, GP, DIP, KP の 順に少なくなる。

再生紙の白色度と炭酸ガス発生量を図 12 に示す。 これは豊橋医科大と資源研による白色度が異なる再生 紙（古紙 100\%）について LCA 評価を行ったもので ある。古紙回収から薬品, 抄紙, 流通, 廃率までの範 囲を調查し, 白色度を $57 \%$ から $70 \%$ にあげると炭酸 ガス発生量は $24 \%$ 増加することを明らかにしている。 これは主にDIP 製造時の収率減によるスラッジ焼却 量の増加, 電力原単位增, 漂白薬品増に起因する。

これに伴い製造コストも高くなってくる。近年高白 色度の再生紙が望まれているケースが多いが，エネル ギー及びコストの両面からみて，一般のコピー用紙な どは低白色度品が望ましい。

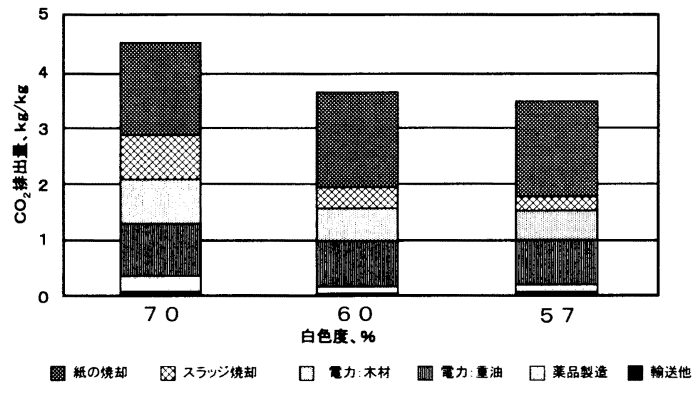

図 12 白色度と炭酸ガス排出量 ${ }^{6 !}$

\section{7. 新しい古紙利用率目標と今後の課題}

続いて日本製紙連合会がまとめた 2005 年度におけ る古紙利用率の自主目標とそれを達成するための課題 を紹介する。なお，この目標は資源有効利用促進法に て正式に定められている。

1995 年度に日本製紙連合会が策定しスタートした 「リサイクル 56 計画」は 2000 年度末が目標達成期限 であったが，前述のように 1999 年度で古紙利用率は $56.3 \%$ となり，困難と予想された目標を前倒しで達 成し, 2000 年度末には $57 \%$ に達し,2001 年度には $58 \%$ を達成するものと推定されている。目標早期達 成の要因は，(1)環境問題に対する配慮から古紙利用製 品（再生紙）へのニーズが高まった，(2)市民・行政・ 企業の環境問題に対する意識高揚により古紙回収が増 加した，(3)規制緩和や企業努力により物流費が低下し た，(4)目標策定時と比較すると古紙価格が大幅に下落 した，(5)製紙各社の環境問題に対する積極的な取り組 みの成果が現れた，(6)古紙処理技術の進歩，利用技術 の進歩により，古紙パルプの高配合が可能になったこ となどである。

新しい目標設定にあたっては現状の分析や将来の予 測に基づく十分な検討を行い, 経済的に達成可能で, 社会的に理解の得られる目標値としている。

古紙技術委員会では主に，(1)古紙利用率の技術的限 界，(2)リサイクル向上における環境評価，(3)古紙価格 と利用率の関係，(4)古紙回収と利用のバランスを中心 に検討が㧍こなわれ，新しい目標値が設定された。こ こではその中の一部を紹介する。 
DIP45\%

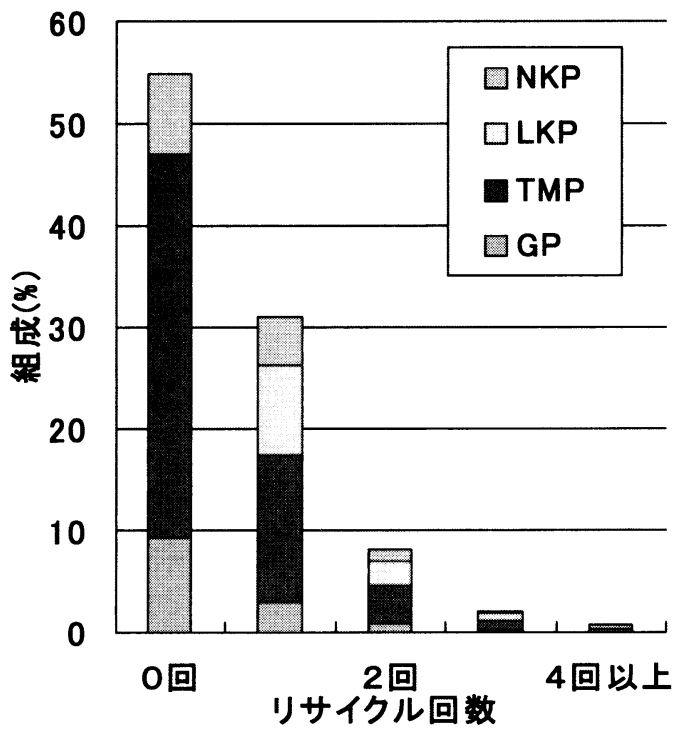

DIP70\%

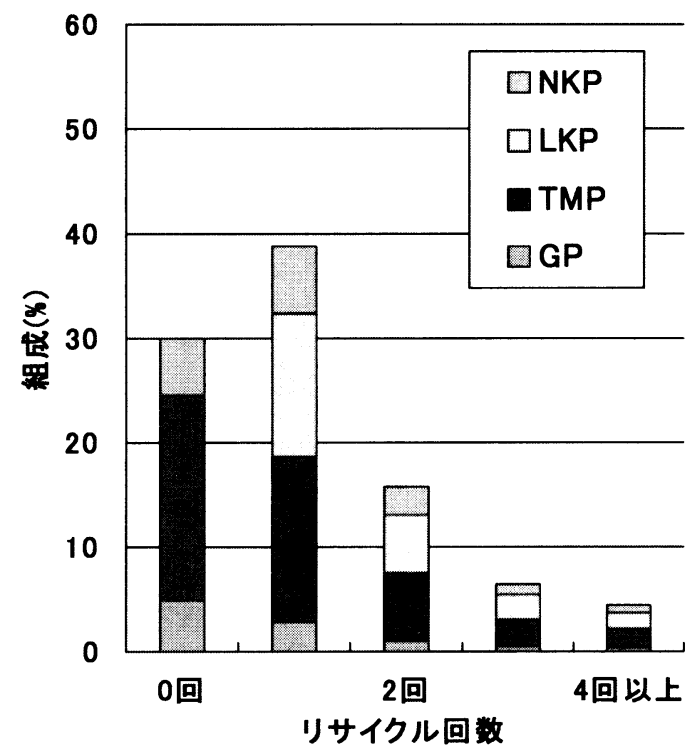

図 13 古紙利用率向上における紙組成変化 ${ }^{8)}$ (新聞用紙中のパルプ組成)

\section{1 古紙利用率の技術的限界}

経済性を全く考虑せずに，品質上および理論的古紙 利用率の限界值について品種毎の検討が行われた。前 提条件としては，(1)顧客の要求する現状品質を維持し, (2)現在の技術の範讲で可能であり，(3)現状と同品質の 古紙が必要な量確保できることなどである。

代表例として新聞用紙の品質上理論的 DIP 配合限 界について紹介する。

チラシ率 $35 \%$ とし, 新聞用紙の組成を現行に近い DIP 配合率 $45 \%$ と DIPを増配して $70 \%$ とした場合 の原料組成変化を図 13 に示す。

この困は種々の前提条件のもとで, DIP $45 \%$ と $70 \%$ の配合率でリサイクルを繰り返した場合のレベルオフ するパルプ組成を計算したものである。

DIP 配合率を 70\%にあげると，リサイクル回数の 多い原料が増加し，チラシの影響も大きくなる。さら にパルプ別の組成をみると，KP が増加し，MPが減 少する。結果として新聞用紙の品質として強度は問題 なく，不透明度が問題になることが想定される。この 対策としてバージンパルプの内 NKP を減少させ, MP を増加させることである程度対応可能である。

しかし DIPを高配合するとバージンパルプの比率 が低下し，原料配合処方の変更のみでは品質要求が維 持できなくなる。このポイントを配合率（利用率）の 限界とした。

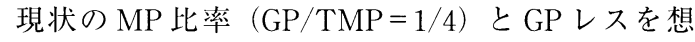

品質上理論的限界: DIP配合率65～70\%

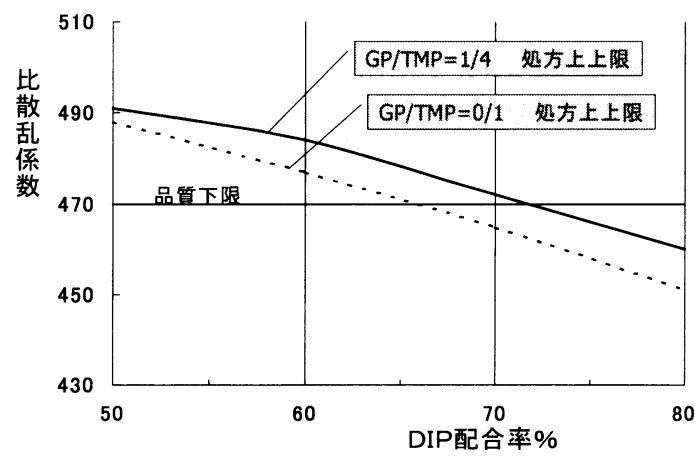

図 14 DIP 配合率と紙質の関係 ${ }^{8}$

定して，TMP 単独の DIP 配合率と紙質の関係をシミ ユレーションした結果を図 14 に示す。

この図からわかるように，不透明度 (比散乱係数) の下限值での DIP 配合率は 65〜 70\% と推定された。

一部で DIP 高配合 $(90 \sim 100 \%)$ 品が生産されてい るが，将来国内で全ての新聞用紙が $80 \%$ 以上に配合 されるようになればこのシミュレーション結果に見 られるように品質維持が困難になるものと思われる。

各品種毎に，新聞用紙の場合と同様にシミュレーシ ヨンした古紙利用率限界を表 5 に示す。洋紙全体で見 ると $46 \%$ となり，新聞用紙と印刷情報用紙の利用率 のアップが可能である。板紙は現状でも古紙利用率は 限界に近づいており, 利用率のアップはほとんど望め 
表 5 品質上理論的古紙利用率限界 ${ }^{87}$

\begin{tabular}{l|c|c|c}
\hline & $\begin{array}{c}\text { 生産量 } \\
\text { (千 } \mathrm{t} / \text { 年 })\end{array}$ & $\begin{array}{c}\text { 現状利用率 } \\
(\%)\end{array}$ & $\begin{array}{c}\text { 限界利用率 } \\
(\%)\end{array}$ \\
\hline 新聞用紙 & 3,295 & 51 & 74 \\
印刷情報用紙 & 11,349 & 24 & 42 \\
包装用紙 & 1,019 & 5 & 12 \\
衛生用紙 & 1,701 & 52 & 55 \\
その他 & 2,029 & 2 & 2 \\
洋紙合計 & 18,393 & 31 & 46 \\
\hline 板紙 & 12,238 & 89 & 91 \\
紙板紙合計 & 30,631 & 56 & 65 \\
\hline
\end{tabular}

ない。紙・板紙合計で見ると約 10\% の増加が可能に なる。

\section{2 古紙回収と利用のバランス}

古紙の回収限界はこれまで $65 \%$ と言われてきたが, 達成可能な古紙回収量と紙・板紙の需要の伸びを考虑 すると, 2005 年には全体の回収率が $62 \%$ となるとい う試算結果が得られた。この中で新聞・雑誌・ダンボ ール古紙の回収率は $90 \%$ と推定している。このデー 夕をべースに古紙利用率を試算すると $60 \%$ が限界と なる。

2005 年には 1999 年と比較して, 全体で更に 280 万 トンの古紙利用増となる。うち洋紙系の主なものは新 聞系 110 万トン，雑誌系 80 万トンである。これらの 古紙を新聞用紙や印刷情報用紙に利用限界範囲内で効 率良く使用しなければならない。
モデル計算では洋紙全体の利用率は $37 \%$ に達する。 しかしながら新聞用紙や中質系印刷用紙においては雑 誌古紙の利用を大幅に増やす必要があり，また上質系 印刷情報用紙において新聞古紙と雑誌をあわせて 120 万トン程度使用する必要があるなど，種々の問題点を 抱えている。

\section{3 目標達成のための課題}

この目標を達成するためには古紙利用製品の使用拡 大や白色度などの品質要求の適正化, 分別回収の徹底, オフィス古紙の有効な回収・利用システムの普及，リ サイクル指向型製品の開発, 紙以外の古紙利用の推進, リサイクル促進のための税制処置拡大など，製紙業界 独自で解決できる問題は少なく, 関係業界・団体との 協力・連携が必須である。

また持続可能な循環型社会を早期に構築するために は，行政・関係業界・団体・消費者が自己の責任を果 たすのみではなく，お互いが協力して全体の効率化・ コストミニマム化を追及することが重要である。

\section{参考文献}

1）紙・パルプ統計年報（経済産業省）（2000）

2）古紙需給統計（古紙再生促進センター）（2000）

3）日本製紙連合会資料（1999）

4）日本製紙(侏)環境報告書（2001）

5） 高柳晴夫：紙パ技協誌 55（7）34４8（2001）

6）桂徹：紙パ技協誌５5（10）10～17（2001）

7）桂徹：紙パルプ技術タイムズ 2001 年 6 月 P. 28

8）二艘木司：紙パ技協誌 55（10）37～44（2001） 